\title{
Effects of Audiovisual, Audio, and Visual Presentations on EFL Learners' Writing Skill
}

\author{
Maliheh Ghaedsharafi \& Mohammad Sadegh Bagheri, Ph.D \\ Shiraz Azad University, Iran \\ E-mail: malihesharafi@yahoo.com
}

\author{
Received: December 16, $2011 \quad$ Accepted: January 31, $2012 \quad$ Published: April 1, 2012 \\ doi:10.5539/ijel.v2n2p113 \\ URL: http://dx.doi.org/10.5539/ijel.v2n2p113
}

\begin{abstract}
This study was designed to find whether three different presentations, i.e. audiovisual, visual and audio, affect EFL learners' writing ability. First, before doing the main research, the researcher piloted her study. Then, 45 students, both males and females, aged from 23 to 38, were selected randomly out of advanced level EFL learners at an English Institute in Shiraz, Iran and they were also divided into three groups of 15. Three documentaries, i.e. stress, superstition and nature tech, were selected (www.YouTube.com) as audiovisual materials. The texts of the very documentaries were used as the visual or reading materials and the listening forms of the same documentaries were applied as the audio materials. The participants were asked to write about the topics once before each mode of presentation and after. The writings were scored out of nine based on IELTS writing criteria by two raters. Inter-rater reliability was calculated between each set of scores. One-way ANOVA, matched $t$-test and the effect size were used. The results revealed that the audiovisual group performed better than the audio group and the audio group performed better than the visual group in their post-writings.
\end{abstract}

Keywords: EFL learners, Writing skill, Audiovisual presentation, Visual presentation, Audio presentation

\section{Introduction}

Nothing is learned in vacuum. Moving from the notion of writing as product to writing as process and the notion of integrating skills has caused the researchers to integrate some skills or materials to the writing skill (Richards and Renandya, 2002). Reading is a kind of visual aid which can be used in writing classes. Specifically, reading is a material through which writing skill improves (Boran, 2009). Today, many researchers and theorists believe that reading and writing are usually described as "parallel processes" or "natural partners" (Trosky and Wood, 1982; Tierny and Pearson, 1983; Tsai, 2008) where the activities of readers are mirror images of the activities of writers (Smith, 1983). On the other hand, Richards and Renandya (2002) believe some materials such as videos and software can stimulate writing. Since the three areas of interest are the effects of reading as a visual presentation, listening as an audio presentation, and documentaries as the audiovisual presentations, the researcher has surveyed the effects of each mode of presentation on EFL learners' writing skill. Besides, the effects of these three presentations have been compared and contrasted.

In EFL classes, readings (i.e., newspaper articles, poems, stories, formal or informal letters, application forms, critiques, notes, messages, etc.) can be used in teaching writing so that learners can take them as models of the written discourse of their target language since they represent the rhetoric, texture, various genres, and styles of the written discourse of English (Boran, 2009). Krashen (1987) believes that through reading we have the opportunity of being exposed to well-organized and well-written pieces of writing which help us to improve our language abilities and to build writing schemata. Casanave (2004), states that writing is a social practice which requires deep engagement with readings and with other writers. Even in the writing class, reading a text is important because they will give the students many ideas and they will give them a lot of good writing styles and useful sentences which must be some help for the students. Escribano (1999) has concluded that Text analysis is an important means for building schemata for writing.

Owing to the fact that audio materials can be used in EFL classes; it may affect writing skill. Reid has investigated the use of listening in writing classes. Reid (1995) has concluded that listening is an input for writers. When we are writing, we often become keenly aware of information, serendipities that relate to what we 
are writing about. We can also train ourselves to listen for details that will be helpful in future writing (Reid, 1995).

Film is one of the visual aids that can be used in a writing class. It makes lessons more fun. It can also be used to create a situation for writing classes in which the students have big enthusiasm in learning the process of writing (Harmer, 2001). Besides, authenticity, according to Morrow (1977), is a stretch of real language, produced by a real speaker or writer, for a real audience and designed to convey a real message of some sort. Hsu (2011) (has investigated consistency of tenses is required) the extent to which the gap between the passive/receptive and active/productive vocabulary of EFL learners is narrowed in a college freshman composition class with the YouTube video clips needs paraphrasing). Moreover, Hsu (2011) that multimedia appeares to provide additional channels for exposure to English. As such, reading-to-write may no longer be the exclusive task in the composition classroom. A number of researchers have discussed the effects of presenting information using multimedia on second language vocabulary acquisition and so on improving main skills especially writing (Akbulut, 2007; Kim \& Gilman, 2008). For instance, (Lin (2004) has found out that audiovisual aids affect vocabulary learning leading to writing improvement.

Furthermore, there are some reasons why teachers and some researchers have tried to use other materials in writing classes for the purpose of writing improvement. First, writing is a complex meta-cognitive activity that draws on an individual's knowledge, basic skills, strategies, and ability to coordinate multiple processes (Graham, 1997). Writing is a difficult skill because it requires writers to have a great deal of lexical and syntactic knowledge as well as principles of organization in L2 to produce a good writing. Second, learners need to have a certain amount of L2 background knowledge about the rhetorical organizations, appropriate language use or specific lexicon with which they want to communicate to their readers. The last point which has been noted by many researchers (Arcario and Stempleski, 1992; Flynn, 1998; Hsu, 2011; Mayer, 2002; Rieber, 1991; Tajima, 2006; Tuttle, 1975) is the lack of motivation in writing classes which can be the result of the lack of exposure to authentic language materials such as visuals, audios, or audiovisuals.

The three modes of presentation have been considered in the research so that it could reduce the lack of motivation, the lack of exposure to the real language and the difficulty of writing.needs paraphrasing, poorly stated.

\section{Research Questions}

1) Does audio presentation affect EFL students' writing abilities?

2) Does audiovisual presentation, such as documentaries, affect EFL students' writing abilities?

3) Does visual presentation, such as reading, affect EFL learners' writing abilities?

4) Which one of the presentations, i.e. audio, visual, audiovisual, affects writing abilities most?

\section{Methodology}

\subsection{Pilot Study}

The research materials and procedures were piloted before launching the main project. In other words, by going through piloting procedures, a great deal of frustration and possible extra work was avoided.

The pilot study was done in two writing classes of Azad University in Shiraz, Iran. Participants were MA students who studied English teaching. They had a writing course in the first term. There were 6 students in each class, both males and females, aged from 24 to 40. The researcher applied two modes of presentation in classes. At first it was aimed to see whether films can affect students' writing or not. Then, another mode of presentation which was listening or audio material was added. One topic was chosen for the students. At first students were asked to write about it before they watched the film. After one week, the film was played for the students before they started to write about the same topic again. The same topic was given to the students in the other group though the audio presentation of the very film was provided for them. The writings were corrected based on IELTS writing criteria. Matched $t$ - test was applied to compare pre-writings and post-writings. The means of the post-writings and the pre-writings were compared and it was concluded that the mean of post-writings was greater than the one in pre-writings. Therefore, audiovisual presentation or film and audio presentation or listening could help students perform better on their writings.

\subsection{Participants}

The main study was done in an English institute in Shiraz, Iran. 45 students, both males and females, aged from 23 to 38 , were chosen randomly. All the participants were advanced students who studied pre IELTS at an Institute in Shiraz, Iran. A placement test was given to the students who wanted to participate in IELTS classes. 
In other words, students who wanted to participate in IELTS classes had to pass the test with grades higher than 5.5 out of nine in that exam. Besides, to enter the pre IELTS classes, grade 4 was needed out of 9. Three pre IELTS classes were selected randomly. Each class included 15 students, both males and females. In each class, one mode of presentation was applied; therefore the three classes were named audio, visual and the audiovisual groups.

\subsection{Materials}

Some factors should be considered when we want to chose a film or a documentary for an English class. According to Arcario and Stempleski (1992) length is one factor to consider. Arcario (1992) states that extracts should be brief. Moreover, Stempleski (1992) suggests that 2-3 minute videos will provide sufficient material for a one-hour lesson. Arcario (1992) also suggests that comprehensibility is another major criterion in selecting a video for language learning purposes. Accordingly, three documentaries were chosen in the study (www.youtube.com). The topics were 1) Enemies of Reason and Slaves to Superstition (8 minutes), 2) Nature Tech ( 8 minutes), and 3) Dealing with Stress (12 minutes). The length of the documentaries ranged between 8 and 12 minutes.

The documentaries provided audiovisual materials for the first group of the participants. Then the (script, improper word) of each documentary was extracted to provide the visual material (the reading texts) for the second group of participants. And finally the audio or listening forms of the documentaries were extracted as the material for the third group. Therefore the same topics were given to participants each time though the modes of presentations were different.

\subsection{Data Collection Procedure}

Due to the fact that there were three modes of presentation in the study, three groups of participants were included. The first group was called the audiovisual group the participants of which watched the three documentaries and then started writing. The second group was the visual group in which the participants read the very three texts of the same documentaries, and then started writing. And the third group was the audio group the participants of which listened to the very three documentaries and then started writing.

The audiovisual group: At first, the three mentioned topics were given to the participants and they were asked to write about the topics on the spot, in other words, they had written about the topics by their own background knowledge before the related films were played for them. After one week, the first documentary, called 'the Enemies of reason; the slave to superstition', was played. Its length was 8 minutes. Having finished watching the first documentary, students started writing about the very topic again, immediately. The process was repeated for the other two documentaries during three weeks.

The visual group: At the same time, the same topics were given to the participants in this group. At first, students wrote about the very topics at home based on their own background knowledge. Then, after one week the first text was given to them and they were asked to write about the same topic again. The other two related texts were also given to the participants during two weeks. All in all, a set of pre-writings and a set of post-writings were gathered. The audio group. Just like the two previous groups, pre-writings had been collected before the participants were asked to listen to each audio material. In the first week, the listening form of the first film was played for the students and after that the students were asked to write about the topic again. The same process was applied for the rest of the topics during three weeks. It should be mentioned that the three topics for each presentation were the same, though the modes of presentations were different.

\subsection{Data Analysis Procedure}

Two series of writings were gathered, pre-writings and post-writings which were rated by IELTS writing criteria (www.examenglish.com/IELTS/IELTS_Writing_MarkSchemes.htm). The writings were scored out of nine which is the standard grade for IELTS. Moreover, the writings were rated by two raters, the researcher herself and another colleague so that the grades wouldn't be biased. Furthermore, the researcher was trained for the grading system for 5 sessions by an expert at the institute, and the other rater was the teacher who taught IELTS and was familiar with the grading system of IELTS exams.

As Brown (2005) suggested, two types of reliability, i.e. inter-rater and intra-rater reliability, are necessary in language testing situations when raters make judgments and give scores for the language produced by the students. The researcher applied inter-rater reliability to calculate the correlation coefficient between the two sets of scores. Besides, before calculating the correlation coefficient, not English) the linear correlation between the variables and the outliers were shown in the scatter plots in SPSS. 
Two one-way ANOVAs, one for the pre-tests of the three groups and the other one for the post-tests of the three groups were also applied. Then, the post hoc analysis was done to have two by two comparisons subsequently. In the post hoc, the Scheffe test was used, too. Besides, the researcher applied matched $t$-test and the effect size to see how great the effect of each presentation was.

\section{Results}

\subsection{Inter-rater Reliability}

The two sets of scores were entered into SPSS program. Since there were pre-writings and post-writings for each student, the procedure was repeated for pre-writings and post-writings separately. Besides, due to the fact that the research was done in the situation where three topics were involved in the three groups, i.e., audio, visual and audiovisual, the reliability for each topic was calculated separately. The average of the correlations of pre-writings and post-writings of each group was calculated and the results are shown in Table 1.

$<$ Insert Table 1 Here $>$

All the sets of scores given by the two raters were highly correlated in each group since all the correlations were significant (significance level $=.000$ ) and all the correlation coefficients were high.

\subsection{One-way ANOVA}

In statistical analysis, one should apply one-way ANOVA if the independent variable has more than two levels. In this study, the independent variable had three levels. (One-way ANOVA was applied for the analysis of variance. The researcher calculated two one-way ANOVAs, one for pre-writings and another for the post-writings though she applied one-way ANOVA for each topic in isolation. After calculating one-way ANOVA, the post hoc analysis was applied in order to have two by two comparisons.

The significance level of each calculation should be less than .010r .05 to reject the null hypothesis. The significance level of the pre-writings did not need to be less than.01 or .05 . In other words, the difference between the pre-writings did not need to be significant though the difference between post-writing scores needed to be significant so that the null hypothesis would be rejected and the differences between the three groups would be significant.

4.2.1 One-way ANOVA for Pre-writings and Post-writings on the Subject of 'Nature tech'. One-way ANOVA was applied to compare all the pre-writings and post-writings of the three groups, audiovisual, visual and audio. The significance level of pre-writings was .121 which represented that the difference between the pre-writings was not significant. Table 2 represents the significance level of all post-writings.

$<$ Insert Table 2 Here $>$

In Table 2, the significance level is .002 which is less than .05 . Therefore, the difference between the post-writings of groups is significant. In other words, it was concluded that the effects of the three modes of presentation differ in writing classes, since the difference between the three groups was significant. Besides, the post hoc was calculated, as it is shown in Table 3, to see which group was the best.

$<$ Insert Table 3 Here>

The computer added an asterisk where the difference between means was significant in the post hoc table. The significance level for the comparison between film and reading was .010 which was smaller than .05 . As a result, the difference between means was significant. Besides, the mean difference was positive which meant that the mean in film group was greater than the mean in reading group. Therefore, the audiovisual presentation or film affected learners' writing abilities more. Moreover, by looking at the significance level of the comparison between reading and listening, the researcher drew the conclusion that the difference between the means was significant $(\mathrm{p}=.007)$ and the mean difference was also negative, as a result, the listening or the audio group performed better than the reading or the visual group.

4.2.2 One-way ANOVA for Pre-writings and Post-writings on the Subject of 'Stress'. The same procedure was applied for the second subject, 'Stress'. The pre-writings and post-writings of the three groups were compared. The significance level of pre-writings was .421 which was more than .05; therefore the difference between them was not significant. The results of post-writings are shown in Tables 4 . and 5.

$<$ Insert Table 4 Here $>$

The difference between the groups was significant since the significance level was less than .01 ( $p=.000)$ (Table 4). Therefore, there were differences between the three groups. The two by two comparisons are in the post hoc table (Table 5). 
$<$ Insert Table 5 Here $>$

The difference between film and reading groups was significant, because the significance level was less than.05. Besides, the mean difference of film was greater than the mean difference of the reading group since the mean difference was positive. Moreover, the difference between reading and listening group was also significant (sig. $=.003$ ) though the mean difference was negative which represented that the mean of listening group was greater than the mean of reading group. At last, the significance level of the mean between film and listening was not significant. In other words, the mean difference of listening and film group was not noticeable.

4.2.3 One-way ANOVA for Pre-writings and Post-writings on the Subject of 'Superstition'. One-way ANOVA for pre-writings and post-writings on the subject of 'Superstition' was calculated. The significance level of pre-writings was .288 which was more than .05 .

\section{$<$ Insert Table 6 Here $>$}

Though the difference between the pre-writings of all groups was not significant, the difference between the post-writings was significant since the significance level was less than $.05(\mathrm{p}=.001)$. In other words, the effects of the three modes of presentation differed. The two by two comparisons are brought here in the post hoc table (Table 7).

\section{$<$ Insert Table 7 Here $>$}

Four asterisks are shown in Table 7 which represents the significant mean difference between film and reading, reading and film, reading and listening, and listening and reading. Two main asterisks represented the mean difference between the film and reading group, and the reading and listening group. In other words, the significance level of the mean difference between film and reading was .002 which was smaller than .05 , and the significance level of the mean difference between reading and listening was .039 which was less than .05 . Moreover, the mean difference between film and reading was positive, so the researcher concluded that the mean of the film group was greater than that of the reading group. On the other hand, the mean difference of the reading and listening group was negative, therefore, the mean difference of listening was greater than the mean difference of the reading. Finally, the significance level of the mean difference between film and listening was .473 which was greater than .05 . Therefore, the researcher concluded that the difference between film group and listening group was not significant.

\subsection{Matched $t$-test and the Effect Size}

The researcher applied matched $t$-test and the effect size of all pre-writings and post-writings in each group to show how great the effect of each presentation was. To find out the effect size of the means, the researcher calculated the square of $t$ value divided by the square of $t$ value plus df. If Eta squared equals .01 it represents a small effect, if Eta squared equals .06, it shows the moderate effect and if it is greater than .14, it represents a large effect (Brown, 2005).

$<$ Insert Table 8 Here $>$

As Table 8 represents, the significance levels of audiovisual and audio groups are less than .01 and .05 . Therefore, the audiovisual presentation and the audio presentation had some effects on EFL learners' writing ability. On the other hand, the significance level of the visual group is more than .01 and .05 , so we can't find any effects of reading on their writing. Besides, by looking at the effect sizes of the groups, we can draw the conclusion that the effect size of the audiovisual group is greater than the effect size of the audio group.

\section{Discussion}

Since the significance level was smaller than .05 . The audio presentation had some effects on EFL learners' writing ability. Besides, the audiovisual presentation affected EFL learners' writing ability because of the significance level which became smaller than .05 . As the significance level of the visual group became greater than .05 , reading did not affect EFL learners' writing ability. The results of the two methods, matched $t$-test and one-way ANOVA, represented that the visual presentation or reading did not affect EFL learners' writing ability. Students did not even copy a word or structure from the reading text that they had. They just got a few ideas or examples. They were not motivated to read a text in comparison to the other mode of presentation. The effect of visual presentation on EFL writing ability was not noticeable. Besides, the effect sizes presented that audiovisual presentation was more effective. Writings of the audiovisual group were rich since the participants applied new ideas and examples, they also performed better grammatically.

Since, many researchers and theorists believe that reading and writing are usually described as "parallel processes" where the activities of readers are mirror images of the activities of writers (Smith, 1983), the reading 
as a visual material was considered in this study. One of the researchers who did the study in the case of reading and writing was Escribano (1999) who surveyed teaching writing through reading in which he informed us that text analysis was an important means for building schemata for writing. All the above researchers found out that writing skill improved most rapidly when students did more reading. Furthermore, they believed that through reading they had the opportunity of being exposed to well-organized and well-written pieces of writing which helped them to improve their language abilities and to build writing schemata. But in this study, the researcher found out that reading did not have any eye-catching effects on EFL students' writing abilities. In other words, film and listening had more noticeable impact on EFL learners' writing abilities.

In the case of using audio materials in writing classes, one study was done by Reid (1987) who surveyed the effects of listening on writing. He concluded that listening was an input for writers. Besides, he believed when students were writing, they often became keenly aware of information, serendipities that related to what they were writing about. Students also trained themselves to listen for details that would be helpful in their writing. The results of this study also represented the remarkable effects of listening as an audio material on students' writing abilities.

Another material which was used by some researchers in EFL learning classes was audiovisual material though its use in writing classes was little. Harmer (2001) proved that film created a situation for writing classes in which the students had big enthusiasm to learn the process of writing. Besides, (Hsu (2011) investigated the extent to which the gap between the passive/receptive and active/productive vocabulary of EFL learners was narrowed in a college freshman composition class with the YouTube video clips incorporated and examined its effect on advanced vocabulary use in writing. He concluded that the ever-increasing presence of multimedia technology provided writing classes with a new tool to improve writing. As the results of this study showed, the audiovisual material affected writing abilities better than audio materials and visual materials.

\section{Conclusion}

Generally, some effects of the documentaries and the audio presentations were derived while the two raters were scoring the writings. Many new ideas and examples were derived from the documentaries and then the audio presentations. The ideas were better arranged in the post-writings. New perspectives towards the issue were also used in post-writings. Many new words were also applied in the post-writings though the students did not know how to use some of them. A wide range of vocabulary was derived from the documentaries and then the listening.

One conspicuous point to be taken into consideration is the fact that, apparently the audiovisual materials have induced a better motivation for the learners to write about the topics provided, than any other one.

The peculiar point is the fact that although it has been long taken for granted that the visual practices (reading) can have better and more efficient results on students' writing ability, it is proven wrong here in comparison to the other two presentations. So, the point the researcher is trying to make is that, presumably it could be a great idea if the students could do the writing part by taking advantage of the audiovisual materials and not just the visual ones.

\section{References}

Akbulut, Y. (2007). Effects of multimedia annotations on incidental vocabulary and reading comprehension of advanced learners of English as a foreign language. Instructional Science, Vol. 35, pp. 499-517. http://dx.doi.org/10.1007/s11251-007-9016-7

Arcario, P., \& Stempleski, S. (1992). Video in second language teaching: Using, selecting and producing video for the classrooms. Alexandria, VA: TESOL Publications.

Boran, M. (2009). Education the educators Retrieved 16 July, 2009, from $\mathrm{http} / / / \mathrm{www}$. Siliconrepublic.com/news/news.nv?storyid=single9104

Brown, J. D. (2005). Testing in language programs. Mac Graw: Hill ESL/ELT.

Casanave, C. (2004). Believes and realities: A framework for decision making in controversies in second language writing. University of Michigan Press, Vol. 45, pp. 7-25.

Escribano, P. D. (1999). Teaching writing through reading: A text-centered approach. IBERICA,Vol. 1, pp. 55-62.

Flynn, K. F. (1998). Bring language to life! Using video in EFL/ESL language program. ESL Magazine Online, 34. Retrieved May 20, 2003, from http://www.eslmag.com/ Marapr98art.html 
Graham, S. (1997). Executive control in the revising of students with learning and writing difficulties. Journal of Educational Psychology, Vol. 89(2), pp. 223-234. http://dx.doi.org/10.1037/0022-0663.89.2.223

Harmer, J. (2001). The practice of English language teaching. Edinburgh: Longman.

Hsu, W. (2011). YouTube in an EFL composition class. Arab World English Journal, Vol. 2, pp. 91-132.

Kim, D., \& Gilman, D. A. (2008). Effects of text, audio, and graphic aids in multimedia instruction for vocabulary learning. Educational Technology \& Society, Vol. 11(3), pp. 114-126.

Krashen, S. (1987). Principles and practice in second language acquisition. New York: Prentice Hall.

Lin, L. F. (2004). EFL learners' incidental vocabulary acquisition in the video-based CALL program. Asian EFL Journal, Vol. 12, pp. 37- 49.

Mayer, R. E. (2002). Multimedia learning: The psychology of learning and motivation. San Diego, CA: Academic Press.

Morrow, K. (1977). Authentic texts in ESP. In Holden, S. (Ed). English for specific Purposes (pp. 13-15). London: Modern language publications.

Reid, J. (1987). The place of genre in learning: Current debates. Geelong, Vic.: Deakin University Press.

Reid, M. J. (1995). Learning Styles in the ESL/EFL Classroom. Boston: Heinle \& Heinle.

Richards, J. C., \& Renandya, W. A. (2002). Methodology in language teaching. Cambridge: University Press. http://dx.doi.org/10.1017/CBO9780511667190

Rieber, L. (1991). Animation, incidental learning and continuing motivation. Journal of Educational Psychology, Vol. 83, pp. 318-328. http://dx.doi.org/10.1037/0022-0663.83.3.318

Smith, F. (1983). Reading like a writer. Language Arts, Vol. 60(5), pp. 558-567.

Tajima, K. (2006). Raising students' motivation for writing: Blending some TESOL theories and applying to the writing class. Academic Reports, Vol. 29, pp. 10-15.

Tierney, R.J., \& Pearson, P.D. (1983). Toward a composing model of reading. Language Arts, Vol. 60, pp. 568-580.

Trosky, O. S., \& Wood, C.C. (1982). Using writing model to teach reading. Journal of Reading, Vol. 26 (1), pp. $34-40$.

Tsai, C. C. (2008). The preferences toward constructivist Internet-based learning environments among university students in Taiwan. Computers in Human Behavior, Vol. 24 (1), pp. 16-31. http://dx.doi.org/10.1016/j.chb.2006.12.002

Tuttle, H. G. (1975). Using visual materials in the foreign language classroom. Learning Resources, Vol. 2, pp. 9-13.

www.examenglish.com/IELTS/IELTS_Writing_MarkSchemes.htm

Table 1. Correlations of the sets of scores in each group for each topic

\begin{tabular}{|c|c|c|c|}
\hline & "Nature tech" & "Stress" & "Superstition" \\
\hline Audiovisual group & Sig. $=.000$ & Sig. $=.000$ & Sig. $=.000$ \\
& 0.814 & 0.809 & .851 \\
\hline Audio group & Sig. $=.000$ & Sig. $=.001$ & Sig. $=.000$ \\
& 0.911 & 0.912 & 0.937 \\
\hline Visual group & Sig. $=.000$ & Sig. $=.000$ & Sig. $=.001$ \\
& 0.807 & 0.839 & 0.854 \\
\hline
\end{tabular}


Table 2. One-way ANOVA for post-writings on the subject of 'Nature tech'

\begin{tabular}{|l|r|r|r|r|r|}
\hline & $\begin{array}{c}\text { Sum of } \\
\text { Squares }\end{array}$ & df & Mean Square & F & Sig. \\
\hline Between Groups & 16.078 & 2 & 8.039 & 7.199 & $\mathbf{. 0 0 2}$ \\
Within Groups & 46.900 & 42 & 1.117 & & \\
Total & 62.978 & 44 & & & \\
\hline
\end{tabular}

Table 3. Multiple Comparisons

Post hoc table for post-writings on the subject of 'Nature tech'

\begin{tabular}{|c|c|c|c|c|c|}
\hline & (I) codes & $(\mathrm{J})$ codes & $\begin{array}{c}\text { Mean } \\
\text { Difference } \\
(\mathrm{I}-\mathrm{J})\end{array}$ & Std. Error & Sig. \\
\hline \multirow[t]{6}{*}{ Scheffe } & film & reading & $1.23333(*)$ & .38586 & .010 \\
\hline & & listening & -.06667 & .38586 & .985 \\
\hline & reading & film & $-1.23333(*)$ & .38586 & .010 \\
\hline & & listening & $-1.30000(*)$ & .38586 & .007 \\
\hline & listening & film & .06667 & .38586 & .985 \\
\hline & & reading & $1.30000(*)$ & .38586 & .007 \\
\hline
\end{tabular}

* The mean difference is significant at the .05 level.

Table 4. One-way ANOVA for post-writings on the subject of 'Stress'

\begin{tabular}{|l|c|c|c|c|c|}
\hline & $\begin{array}{c}\text { Sum of } \\
\text { Squares }\end{array}$ & df & Mean Square & F & Sig. \\
\hline Between Groups & 28.744 & 2 & 14.372 & 10.162 & $\mathbf{. 0 0 0}$ \\
Within Groups & 59.400 & 42 & 1.414 & & \\
Total & 88.144 & 44 & & & \\
\hline
\end{tabular}

Table 5. Multiple Comparisons

Post hoc table for post-writings on the subject of 'Stress'

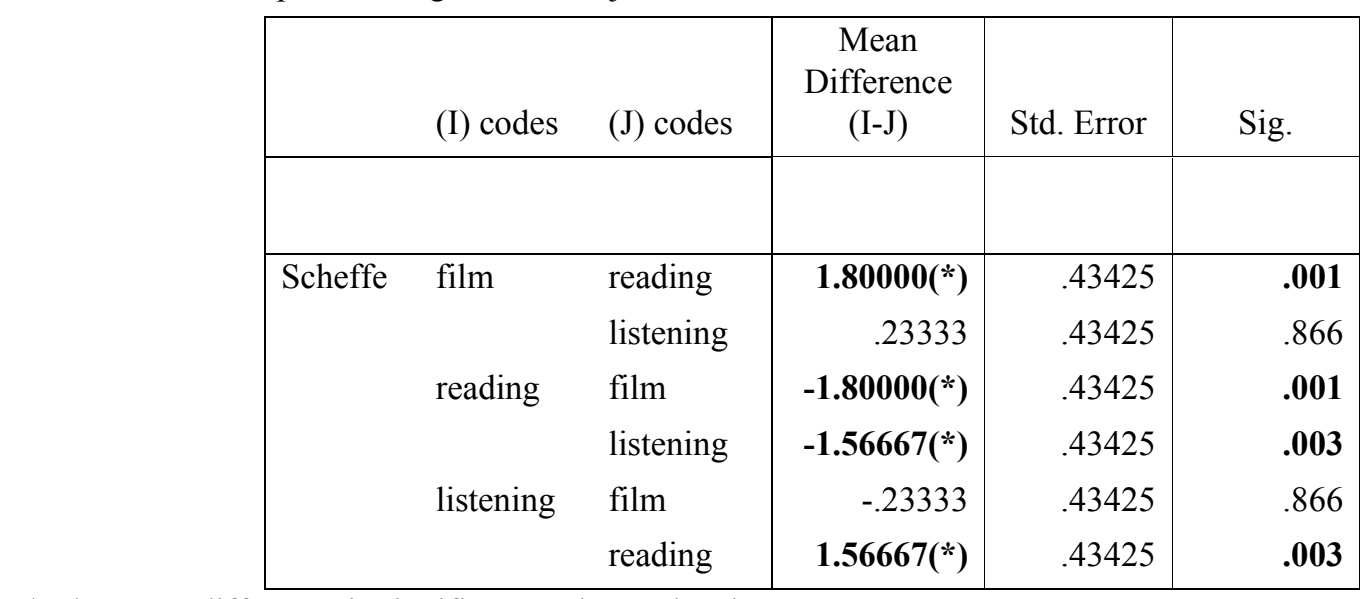

* The mean difference is significant at the .05 level. 
Table 6. One-way ANOVA of post-writings on the subject of 'Superstition'

\begin{tabular}{|l|c|c|c|c|c|}
\hline & $\begin{array}{c}\text { Sum of } \\
\text { Squares }\end{array}$ & df & Mean Square & F & Sig. \\
\hline Between Groups & 16.844 & 2 & 8.422 & 7.867 & $\mathbf{. 0 0 1}$ \\
Within Groups & 44.967 & 42 & 1.071 & & \\
Total & 61.811 & 44 & & & \\
\hline
\end{tabular}

Table 7. Multiple Comparisons

Post hoc table for post-writings on the subject of 'Superstition'

\begin{tabular}{|c|c|c|c|c|c|}
\hline & (I) codes & (J) codes & $\begin{array}{c}\text { Mean } \\
\text { Difference } \\
(\mathrm{I}-\mathrm{J})\end{array}$ & Std. Error & Sig. \\
\hline \multirow[t]{6}{*}{ Scheffe } & film & reading & $1.46667(*)$ & .37782 & .002 \\
\hline & & listening & .46667 & .37782 & .473 \\
\hline & reading & film & $-1.46667(*)$ & .37782 & .002 \\
\hline & & listening & $-1.00000(*)$ & .37782 & .039 \\
\hline & listening & film & -.46667 & .37782 & .473 \\
\hline & & reading & $1.00000(*)$ & .37782 & .039 \\
\hline
\end{tabular}

* The mean difference is significant at the .05 level.

Table 8. The significance level and the effect size of each presentation on EFL learners' writing

\begin{tabular}{|l|l|l|l|}
\hline & "Nature tech" & "Stress" & "Superstition" \\
\hline Audiovisual group & $\begin{array}{l}\text { Sig. }=.000 \\
\text { Effect } \text { size }=.74\end{array}$ & $\begin{array}{l}\text { Sig. }=.000 \\
\text { Effect } \text { size }=.82\end{array}$ & $\begin{array}{l}\text { Sig. }=.000 \\
\text { Effect } \text { size }=.78\end{array}$ \\
\hline Audio group & $\begin{array}{l}\text { Sig. }=.001 \\
\text { Effect } \text { size }=.53\end{array}$ & $\begin{array}{l}\text { Sig. }=.000 \\
\text { Effect } \text { size }=.59\end{array}$ & $\begin{array}{l}\text { Sig. }=.032 \\
\text { Effect } \text { size }=.28\end{array}$ \\
\hline Visual group & Sig. $=.290$ & Sig. $=.217$ & Sig. $=.072$ \\
\hline
\end{tabular}

